\title{
As fábricas de ladrilho hidráulico de Campina Grande [PB]: um estudo do patrimônio industrial
}

\author{
Dossier DE PESQUiSA : PATRIMÔNIO IndUSTRIAL No NoRTE E NoRDESTE Do BRASIL
}

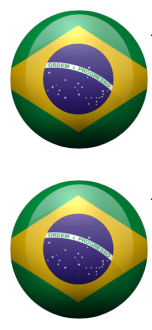

\section{Arthur Thiago Thamay Medeiros}

Doutorando em Design pela UFRGS, Mestre em Design pela UFCG, Especialista em Artes pela Faculdade Internacional Signorelli, graduado em Design de Produto pela UFCG e bacharel em Comunicação Social pela Universidade Estadual da Paraíba. Campina Grande [PB] Brasil. <thiagothamay@hotmail.com>

\section{Alcilia Afonso de Albuquerque e Melo}

Doutora em Projetos Arquitetônicos [ESTAB-UPC], Professora Adjunta do curso de Arquitetura e Urbanismo da Universidade Federal de Campina Grande. Coordenadora do Grupo de Pesquisas Arquitetura e Lugar [GRUPAL]. Campina Grande [PB] Brasil. <kakiafonso@hotmail.com>

\begin{abstract}
Resumo
O presente artigo apresenta uma pesquisa sobre as fábricas de ladrilho hidráulico que funcionaram em Campina Grande, com foco na Fábrica Metro Materiais, a antiga "Fábrica de Mosaicos Resistência", a primeira fundada na cidade inaugurada em 1947 e a única que existe atualmente no Estado da Paraíba. Popularmente conhecido como mosaicos, essa tipologia de revestimento foi um elemento construtivo importante na constituição histórica da arquitetura de Campina. A cidade foi palco de grande desenvolvimento em diversos setores industriais e, por isso, torna-se importante a investigação da trajetória das fábricas de ladrilhos hidráulicos que funcionaram no município. A pesquisa empenhou-se em detalhar o processo de fabricação dos ladrilhos produzidos pela fábrica Metro com o objetivo de registrar as técnicas e as ferramentas desenvolvidas empiricamente, utilizadas no fabrico do produto.
\end{abstract}

\section{Palavras-chave}

Patrimônio industrial. Ladrilho hidráulico. Metro Materiais.

\section{The hydraulic tile factories from Campina Grande [state of Paraiba, Brazil]: an industrial heritage case}

\begin{abstract}
The present article presents a research on the hydraulic tile factories that worked in Campina Grande, focusing on the Metro Materiais Factory, the former "Fábrica de Mosaicos Resistência", the first one founded in the city inaugurated in 1947 and the only one that currently exists in the state of "Paraíba". Popularly known as mosaics, this type of cladding was an important constructive element in the historical constitution of the Campina architecture. The city was a stage of great development in several industrial sectors and, therefore, it becomes important to investigate the trajectory of the hydraulic tile factories that worked in the municipality. The research focused on detailing the process of manufacturing the tiles produced by the Metro factory in order to record the techniques and tools developed empirically used in the manufacture of the product. The importance of the present study is justified because of the scarcity of literature on the subject, resulting in the preservation of history and manufacturing techniques, through the record of the industrial patrimony of Campinense addressed in the research. Thus, the contribution of the results opens the way for future research that works on the divulgation of the history and preservation of the industrial heritage from "Campina Grande".
\end{abstract}

\section{Keywords}

Industrial heritage. Hydraulic tile. Metro Materiais. 


\section{Introdução}

Em compasso com a cultura local, através de sincretismos religiosos e elementos do cotidiano, este tipo de revestimento, enquanto ornamento constitutivo, revela uma interpretação acerca dos seus significados, no qual vêm se apropriando da cultura local, estampando em seus grafismos padrões oriundos de um passado inteiramente presente através dos signos e seus referentes.

Originados dos mosaicos bizantinos, os ladrilhos foram amplamente utilizados desde o século XIX na Europa, África do Norte e América Latina. De base artesanal, com produção manufaturada, os ladrilhos possuem métodos peculiares de produção, passadas de geração à geração, com o intuito de preservar características técnicas na fabricação.

Campina Grande localizada na região agreste do Estado da Paraíba, que outrora foi empório comercial do algodão, na contemporaneidade abarca o título de cidade universitária exercendo, assim, uma influência geoeconômica em limites que transpõem fronteiras estaduais. Após o declínio do comercio algodoeiro na cidade, foi a vez de outros setores industriais crescerem. A produção do LH chegou à Campina Grande através do empresário José Guedes de Andrade que, em 1947, fundou a primeira indústria de ladrilhos hidráulicos em Campina: a Fábrica de Mosaicos Resistência.

Em 1995, Januário Ferreira, neto de José Guedes de Andrade, mantendo a tradição familiar na produção do LH, retomou as atividades fabris no mesmo endereço da fundação da Fábrica de Mosaicos Resistência, agora com o nome fantasia Metro Materiais.

A Fábrica Metro, única licenciada no Estado para produção dos ladrilhos hidráulicos, mantêm-se como patrimônio industrial da cidade e detentora de mais de 230 matrizes de desenho. Conforme as fábricas de ladrilho encerravam suas atividades, vendiam seu maquinário e ferramentas de produção para as demais, reforçando a importância do legado tangível que a Metro detém. Trata-se, também, de um patrimônio visual acerca dos desenhos destes ladrilhos, que remontam a própria história de Campina Grande.

Assim sendo, a presente pesquisa tem como objetivo resgatar historicamente o percurso das fábricas de ladrilho hidráulico no período de 1940 à 1990, investigando o modo como a arquitetura moderna absorvia a demanda das fábricas locais. Deste modo, verificou-se as razões do desuso do ladrilho hidráulico em Campina Grande, para que posteriormente pudesse reconhecer as tecnologias empregadas no processo produtivo.

Como justificativa para a elaboração desse trabalho, enxerga-se a necessidade de um estudo sobre as fábricas de ladrilho hidráulico, possibilitando o registro para a contemporaneidade e fomentação na promoção de mais pesquisas acerca deste patrimônio industrial.

Apesar do ladrilho hidráulico ter retornado ao mercado, a literatura sobre o tema é escassa e a metodologia artesanal de produção segue procedimentos empíricos. Assim, a contribuição dos resultados da pesquisa representa o testemunho de atividades de valor histórico, a qual justifica a inventariação patrimonial de uma fábrica com extensa produtividade.

\subsection{Metodologia da pesquisa}

Quanto à metodologia de trabalho, a presente pesquisa pode ser classificada, através de sua estrutura e seus objetivos como uma pesquisa exploratória, pois, segundo Gil (2008, p. 41), busca proporcionar maior familiaridade com o objeto e torná-lo mais explícito. Partindo da perspectiva do autor, o estudo de caso da presente pesquisa consistirá na análise visual do objeto, de maneira que permita seu amplo e detalhado conhecimento.

Seguindo todas as orientações citadas, a primeira etapa foi coletar dados e listar quais fábricas de ladrilho hidráulico existiram em Campina Grande, classificando e investigando seu percurso histórico. Para isso, a pesquisa trabalhou com ferramentas de registro fotográfico, descrições e fontes documentais existentes. 
Na segunda etapa, o foco de análise se detém no uso e apropriações atribuídas ao ladrilho hidráulico em Campina Grande, observando este elemento construtivo em seu esplendor enquanto revestimento de pisos e paredes nas residências modernas de meados da década de 1960, seu desuso a partir dos anos 1980 e a retomada no uso do ladrilho hidráulico a partir de 1995.

Decidiu-se, então, pelo cruzamento de diferentes fontes que possibilitasse a pesquisa histórica do percurso do ladrilho hidráulico na cidade através da coleta de evidências. Assim, a busca de dados realizada diversas áreas de conhecimento promovendo a integração dos temas que serão desenvolvidos nos capítulos a seguir e propiciando a contribuição de pontos de vista que corroboram na construção de elementos que fizeram parte da trajetória industrial de Campina Grande.

\section{Ladrilho hidráulico}

Para conceituar o ladrilho hidráulico é importante estudar primeiramente aspectos que definem o produto para, em seguida, compreender os aspectos históricos deste revestimento.

A NBR 9457:1986 define ladrilho hidráulico como placa de concreto de alta resistência ao desgaste para acabamento de paredes e pisos internos e externos, contendo uma superfície com textura ou lisa, colorido ou não, de formato quadrado, retangular ou outra forma geométrica definida.

Atualmente existem três tipos de ladrilhos disponíveis no mercado: Ladrilho Hidráulico Interno - utilizado em pisos, paredes ou até mobiliário; Ladrilho Hidráulico Externo - utilizado em ambientes externos como calçadas, dentre outros; e Ladrilho Hidráulico Tátil utilizado nos ambientes externos para garantir acessibilidade aos deficientes visuais. Apre- Figura 1. Da esqueda para a direita: LH interno, externo e tátil. sentam superfícies específicas e padroniza-

das e são encontrados de duas formas: alerta e direcionais (Figura 1).

Após elucidar acerca de todo o conjunto de revestimentos hidráulicos existentes no mercado, para situar o objeto da pesquisa em consonância com o tema patrimônio industrial, que foi explorado na sessão anterior, é importante investiga-lo por meio de um estudo direcionado no reconhecimento do produto ladrilho hidráulico.

Prosseguindo, ainda sobre o objeto de estudo e aprofundando-se mais sobre os aspectos históricos do ladrilho hidráulico, Macedo (2013, p. 17) comenta que a história do LH no Brasil é relativamente nova, datando do final do século XIX. Porém, seus padrões decorativos remontam as formas utilizadas pelas civilizações egípcias e mesopotâmicas, baseados na geometria, "a partir do traçado de um círculo e da linha reta, sendo que o primeiro instrumento de medição conhecido constava de uma corda marcada por doze nós equidistantes e de um suporte fixo de madeira, antecessor ao compasso".

Assim, Macedo (2013, p. 21) descreve que a trajetória dos padrões geométricos até a incorporação nos LH atravessou os séculos e acredita-se que foi com referências artísticas nos mosaicos bizantinos e azulejos portugueses que, possivelmente, inspirou o processo de criação e de fabricação dos ladrilhos hidráulicos.

Corroborando com Macedo (2013), o autor Marques (2012, p. 17-18) afirma que o processo de produção dos ladrilhos hidráulicos data do século XIX, sendo que não existem referências claras da sua origem, supostamente árabe.

O modo artesanal de fabricação, carregado de técnicas repassadas por gerações de famílias que trabalham com esse tipo de manufatura, emprega ao ladrilho hidráulico um caráter intimista visto que seu processo de fabricação detém um passo-a-passo que foi se perdendo ao longo das gerações posteriores. 


\section{Patrimônio industrial}

O conceito de patrimônio industrial, parte do resgate dos vestígios técnicos industriais e os equipamentos técnicos, englobando também os edifícios, os produtos e o próprio arranjo industrial que são considerados objetos de estudos da arqueologia industrial - cujo movimento de defesa do legado industrial surgiu na Inglaterra, nos anos de 1950, em decorrência da destruição de muitas fábricas no período da segunda guerra mundial (Afonso \& Carvalho, 2015, p.3).

Assim, sobre a definição do tema a carta de Nizhny Tagil (TICCIH, 2003) direciona os pesquisadores no sentido do dever de resgatar e investigar os vestígios técnicos-industriais, os equipamentos, os produtos, os registros da própria instituição e demais documentos coletados em fontes primárias e secundárias.

A riqueza do patrimônio industrial está em sua diversidade formal, de uso e de escala. Não engloba somente como patrimônio cultural, o patrimônio material tangível, como as edificações, os maquinários e os documentos, mas também, o patrimônio intangível (Dezen-Kempter, 2007, p.2).

\subsection{O lugar: Campina Grande [PB] Brasil}

Localizada no Agreste do Planalto da Borborema da Paraíba, Campina Grande é considerada a segunda cidade mais populosa da Paraíba, e sua região metropolitana é formada por dezenove municípios. De acordo com estimativas do IBGE (2016, on-line), sua população é de 410332 habitantes. Campina Grande exerce uma influência geoeconômica em limites que transpõem fronteiras estaduais, tornando-se uma das cidades interioranas mais importantes de toda Região Nordeste (Figura 2).

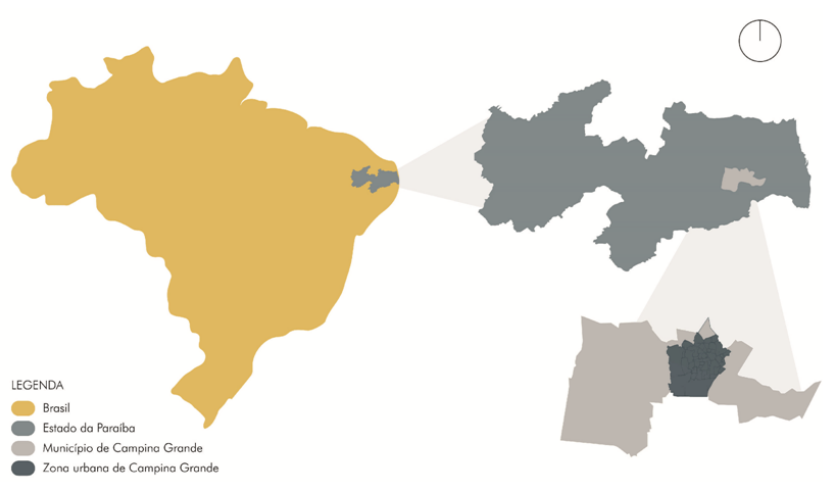

Figura 2. Mapa de localização de Campina Grande [PB] Brasil. Fonte: GRUPAL (2017).

Campina Grande, que inicialmente era uma aldeia dos índios Cariris (cujo nome batizou uma das principais e mais antigas ruas do município), foi palco de grandes acontecimentos históricos, como a revolta do "Quebra-quilos". Em 1790, transformou-se em vila, nomeada a partir daí de Vila Nova da Rainha e somente em 11 de outubro de 1864, foi elevada à categoria de cidade (IBGE, 2016, on-line).

\subsection{Aspectos históricos: urbanização, economia e sociedade}

A urbanização do município teve um forte vínculo com suas atividades comerciais. 0 grande salto de desenvolvimento foi devido às atividades tropeiras e ao crescimento da cultura do algodão, quando a cidade chegou a ser a segunda maior produtora de algodão do mundo.

Em meados do século XIX, a manufatura agroindustrial ancorada principalmente na cana-de-açúcar e no algodão sustentavam a economia paraibana. Oliveira e Rodrigues (2009, p.22) comentam que devido à concorrência com os holandeses, o açúcar caiu de preço no mercado ao passo que os custos da produção só aumentavam, o que levou o algodão a assumir o lugar de destaque na economia do Estado.

A ocupação do espaço territorial de Campina Grande fundamentou-se pela conjugação de interesses mercantis e pelas grandes propriedades agro açucareiras, impulsionadores das atividades criatórias e de subsistência (Silva, 2000, p.13).

A revolução industrial foi responsável por desenvolver no Nordeste brasileiro a lavoura algodoeira, importante como produto à implementação da indústria têxtil, onde passou a interessar o mercado internacional a partir da segunda metade do século XVIII. Campina, então, eclode como centro comercial do algodão de toda Região Nordeste. 
Além de superar a capital do Estado em crescimento urbano e demográfico, também superava em arrecadação de impostos e rendas públicas. Esse desenvolvimento acelerado estava ligado ao algodão desde 1910, quando começou a atrair grande quantidade desta fibra têxtil produzida no interior e nos Estados próximos. Campina Grande assumiu um papel importante na economia da Paraíba como cidade comercializadora do algodão, sendo referência e famosa em todo o Brasil.

O crescimento econômico, comercial, industrial, demográfico e urbano de Campina Grande entre as décadas de 1920 e 1950 foi de uma enorme proporção, visto em poucas cidades brasileiras, passando pela intensificação de um processo de reformulação urbana pautado nos ideais de higiene, circulação e embelezamento (Queiroz, 2016, p. 20).

Neste período, grandes transformações na paisagem urbana da cidade como o realinhamento de ruas, pavimentação, instalação de rede de água e esgoto e a demolição de um conjunto arquitetônico eclético no perímetro central, para dar espaço a construções que atendessem ao plano de progresso e modernidade almejado pelo então prefeito nomeado da época: Vergniaud Borborema Wanderley. Assim, Sá (2000, p. 179) descreve Campina Grande entre as décadas de 1940-1950 como "depois do Recife o mais importante empório comercial de toda Região Nordeste, confirmando sua vocação pretérita iniciada nos séculos XVIII e XIX com a produção de farinha de mandioca".

Queiroz (2016, p. 28) relata que em 1954, Campina Grande possuía mais de 17.240 edificações urbanas e uma população de 173.206 habitantes, número superior ao da capital João Pessoa, que na mesma época possuía 119.326 habitantes. Esses dados reforçam o avanço com que a cidade se desenvolvia, multiplicando o número de construtoras e importadores de material de construção e diversos tipos de fábricas de mosaicos. Com o declínio do ciclo do algodão na cidade e a crise nos setores comerciais varejistas e de serviço, a economia encontra espaço na indústria como retomada da crise.

Vale ressaltar que o crescente número de fábricas de ladrilho hidráulico em Campina foi devido à grande demanda em reformas e construções de imóveis que atendessem aos novos padrões estabelecidos de modernidade e saneamento. Segundo Queiroz (2016, p. 85). Nas reformas o piso era elevado acima do nível da rua por meio de aterros e impermeabilizados com ladrilhos.

Se antes as residências com piso de chão batido eram comuns, o código de Posturas Municipais estabelecidos pela Lei no 140 de 4 de outubro de 1928 definiu que os banheiros, latrinas, cozinhas, copas e adegas deveriam ter as paredes internas revestidas de azulejo, mosaicos ou material equivalente, até a altura de $1 \mathrm{~m}$ e $50 \mathrm{~cm}$ no mínimo e o pavimento revestido de materiais resistentes lisos e impermeáveis (Parahyba, 1928, p. 14, apud Queiroz, 2016, p 147).

\subsection{Recorte histórico do objeto de estudo: 1940-1990}

Iniciando o recorte temporal da pesquisa, na década de 1940 ocorreram dois fatos importantes condutores dos acontecimentos subsequentes que possuem relação com o objeto de pesquisa. Primeiramente, foi datado em 1947 o surgimento da primeira fábrica de ladrilhos hidráulicos de Campina Grande, a "Fábrica de Mosaicos Resistência". O segundo acontecimento importante para Campina Grande, ostentando sua vocação para o setor industrial, foi a fundação da Federação das Indústrias do Estado da Paraíba - FIEP, quando a primeira diretoria tomou posse em 17 de julho de 1949. Em meados de 1940, Domício Velloso da Silveira, Milton Bezerra Cabral, Agostinho Velloso, Daniel Sydentriker e José Marques de Almeida, abraçaram o projeto de criar a FIEP, com sua primeira diretoria eleita para o mandato bienal 1950/1951 (Oliveira \& Rodrigues, 2009, p. 36).

A vanguarda está no fato de sediar um órgão de liderança do processo de industrialização, sendo uma cidade de interior, circunstância que só ocorre nas capitais do Brasil. Sobre a relação da FIEP com o objeto de estudo, sabe-se que a instituição reconhece e outorga na mesma data de fundação da instituição que as fábricas de ladrilho hidráulico enquadram-se na categoria de "Industrias de Transformação de Minerais Não-Metálicos" pelo Sindicato da Indústria de Construção Civil de Campina Grande que rege a categoria em questão (FIEP, 1969).

Posteriormente, em 25 de junho de 1979, foi outorgada pelo Ministro de Estado do Trabalho a abrangência de suas atividades, passando a se chamar "Sindicato da Indústria da Construção Civil e do Mobiliário do Estado da Paraíba", abarcando também a área do design de produto (Figura 3). 


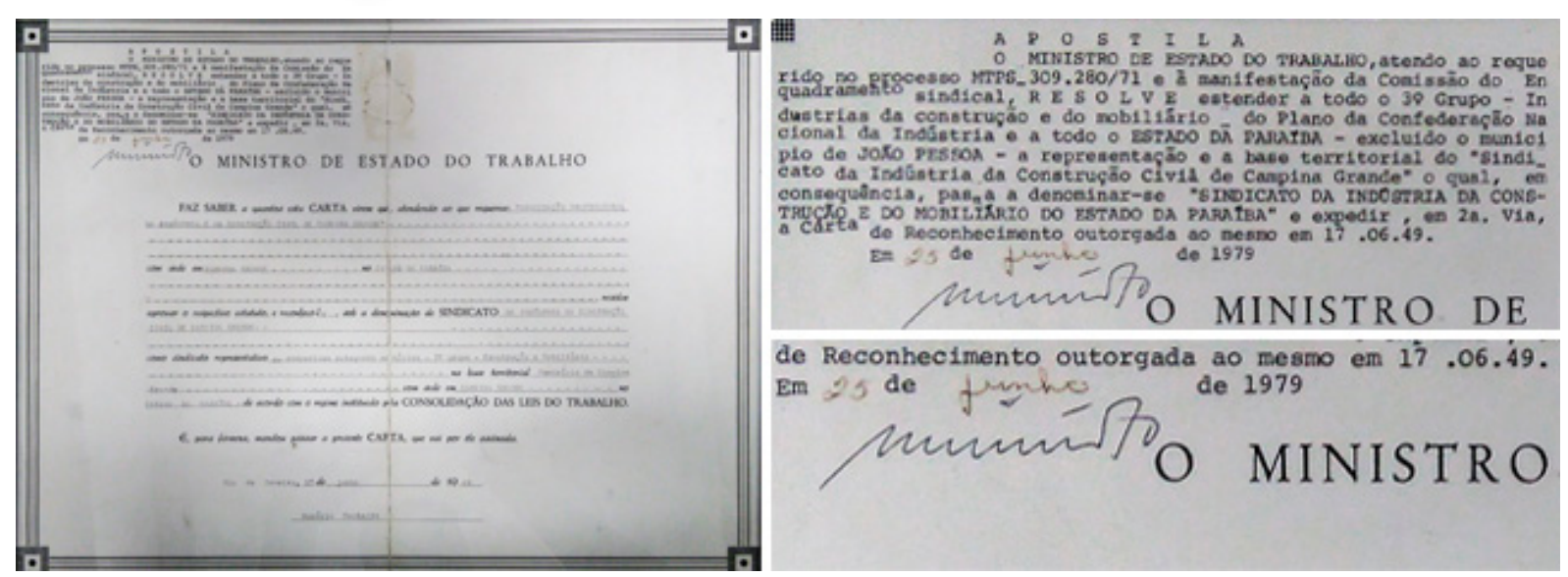

Figura 3. Fotografia do documento do Ministério do Trabalho que outorga a criação do sindicato. Elaborado pelo autor.

Prosseguindo para a década de 1950, Campina Grande estava envolvida por uma atmosfera de otimismo e mudanças que permeavam o imaginário da população e, em meados deste decênio, a cidade experimentava o desenrolar de um novo ciclo de modernização, em compasso com os acontecimentos nacionais e alicerçados nos esforços da elite local para inseri-la no processo de industrialização do país (Queiroz \& Rocha, 2007, p 1).

Afonso e Meneses (2015, p. 5-6) contam que durante a década de 1950 chegavam à cidade as notícias da caminhada rumo ao progresso pelo qual o Brasil estava iniciando, e o percurso fora traçado pelo Plano de Metas do presidente Juscelino Kubitschek. Nos jornais, as fotos da construção de Brasília e manchetes despertavam o sentimento patriótico nos seus leitores.

Segundo Queiroz e Rocha (2007, p. 3), a influência da arquitetura moderna brasileira deu-se, sobretudo, no que se refere à incorporação da tradição erudita e popular, desempenhando um importante papel na constituição da arquitetura local.

Campina Grande finalmente entra na modernidade cadenciada com o movimento de arquitetura moderna que vinha se desenvolvendo no Rio de Janeiro, São Paulo e Brasília. Na cidade, o moderno foi vivenciado com a demolição do patrimônio histórico. 0 progresso era a ordem e como cita Amorim (2000, p.155) "mudar nomes de ruas se tornou algo natural".

Diante deste crescimento, fruto das políticas em prol da urbanização campinense semeado por Vergniaud Wanderley, as fábricas de ladrilho hidráulico começaram a se instalar na cidade, encontrando na inovação um mercado para consumo dos novos revestimentos.

Segundo dados do Anuário de Campina Grande (1950) e através de coleta em jornais que circulavam em Campina Grande na década de 1950, constatou-se através dos anúncios publicados ao longo dos periódicos, no decênio de 1950 existiram três fábricas de ladrilho hidráulico na cidade (Figuras 4 a 7).

Apesar da Federação das Indústrias do Estado da Paraíba ter sido constituída em 1949, não houve registro oficial na instituição sobre tais fábricas da década de 1950 em Campina Grande. Assim, estas pequenas empresas, mesmo funcionando sem registro, em sua ilegitimidade, iniciaram o percurso histórico da fabricação local do ladrilho hidráulico.

Assim como o proprietário da Fábrica Resistência, os demais empresários do segmento usaram em seu benefício a constante expansão e acelerado crescimento da qual Campina Grande usufruía. Foi a vez da indústria movimentar a economia local.

O pioneirismo da Fábrica de Mosaicos Resistência também se deu na fabricação de cobogós. Enquanto seus concorrentes se detinham apenas na fabricação de ladrilhos, ela trazia como diferencial competitivo de venda os elementos vazados de cimento.

Daí em diante, a Lei Municipal no 47 de 8 de agosto de 1958, concebeu incentivos às indústrias novas que viessem a se instalar em Campina Grande gozando de isenção de impostos municipais, pelo 
prazo de dez anos. Estes benefícios são ainda complementados pela Lei Estadual no 1.564 de 25 de outubro de 1956, regulamentada pelo Decreto no 1.095 de 27 de novembro de 1956 em que o Governo Estadual concede isenções de todos os impostos estaduais às indústrias de cunho econômico sem similares ou novas que forem instaladas no Estado da Paraíba (PMCG, 1964, p 13).

\section{Industria de "Mosai- cos Gusmão" MANUEL BATISTA GUSMAIO \\ Rua Eol. Jouno da Sillia Pimentel gf. 18 r End. Teleg: "MOSAICOS" \\ CAMPINA GRANDE - PARAIBA \\ A Industria de Mosaicos "Gusmão" convida os Srs. Proprietarios e Construtores de todo o Estado para uma visita ao seu estabeleci- mento, onde melhor veriflcarão a belesa re sistencia e otimos preços de seus produtos. Tambem encarrega-se de qualquer trabalho - em granito. - \\ Industria de Mosaicos "GUSMÃO" \\ Rua Qel. João da Silva Prmentol, 18 r Campina Grande - Paraíba}

\section{Fabrica de Mosaicos S. JOSE' \\ Soc. de Espansão Comercial e Industrial Ltda. SOECIA

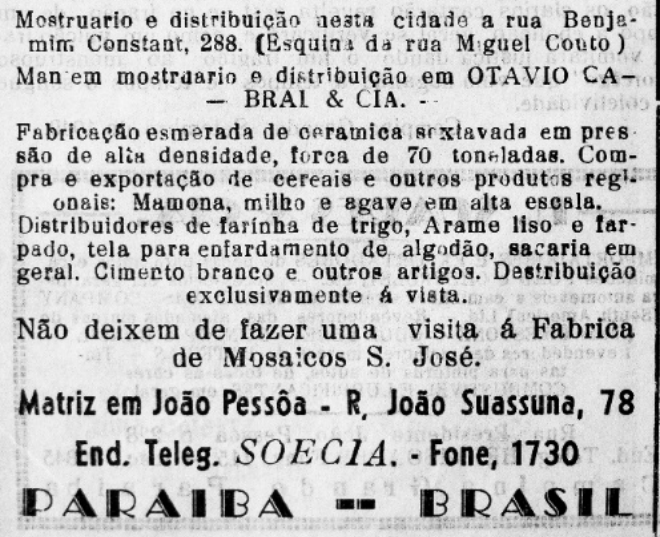

Figura 4. Anúncios do Jornal 0 Rebate (16/08/1950) Fonte: Acervo da biblioteca do Museu de Artes Assis Chateaubriand.
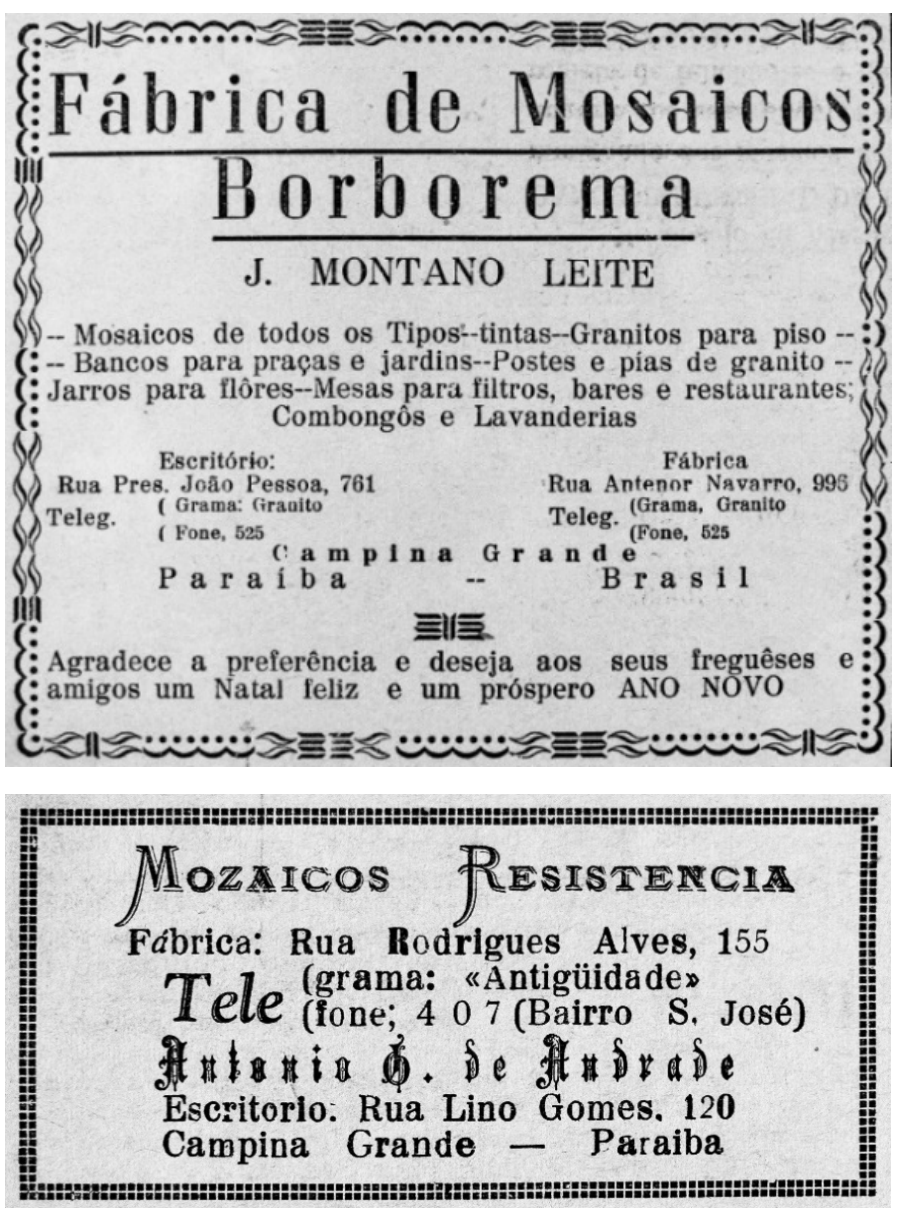

Figura 6. Anúncio do Jornal O Rebate (21/06/1950).

Fonte: Acervo da biblioteca do Museu de Artes Assis Chateaubriand.
Figura 5. Anúncio do Jornal de Campina Grande (25/12/1955).

Fonte: Acervo da biblioteca do Museu de Artes Assis Chateaubriand.

\section{Anionio G. de Andrade}

Mozaicos Resistência

Fáb. - Rua Rodrigues Alves, 155

Teleg. , "ANTIGUIDADE"

Fone, 407 - (Bairro S. José)

Esc. - Rua Lino Gomes 120 CAMPINA GRANDE - PARAÍBA

Figura 7. Anúncio publicado na Revista Ariús (1953). Fonte: Acervo da biblioteca do Museu de Artes Assis Chateaubriand. 
A fim de descentralizar os incentivos econômicos do Brasil, que antes era, em sua maioria, para o sul e sudeste, era preciso criar condições para que as empresas se deslocassem até outras regiões do país. Com isso, foi criada a SUDENE no ano de 1959, através da Lei no 3.692, como uma forma de intervenção do Estado no Nordeste, com o objetivo de promover e coordenar o desenvolvimento da região, através de uma autarquia subordinada diretamente à Presidência da República, e sua Secretaria Executiva. Coube a Celso Furtado de 1959 a 1964, a responsabilidade pela estratégia de atuação do órgão (Afonso, 2017, p. 6).

A Superintendência do Desenvolvimento do Nordeste - SUDENE, é uma autarquia especial, administrativa e financeiramente autônoma, integrante do Sistema de Planejamento e de Orçamento Federal, com sede na cidade de Recife [PE], e vinculada ao Ministério da Integração Nacional (SUDENE, 2017, on-line).

Anterior à Sudene, criou-se em 1957 um organismo paralelo à administração pública: a Fundação para o Desenvolvimento da Ciência e da Técnica: FUNDACT. De acordo com Lima (1996, apud Alves, 2012, p. 48), "esta fundação, no período anterior à Sudene, procura orientar os industriais locais e os que desejarem se instalar na região, através de assessoria e elaboração de projetos industriais. Também tenta financiamentos e incentivos dos governos para estas indústrias".

Alves (2012, p. 48) ainda cita que mesmo depois da criação da SUDENE, a FUNDACT continuou a atuar na orientação dos industriais de Campina, elaborando um guia de investimentos concedidos pelo Governo Federal, Estadual e Municipal, sendo de fundamental importância para que a cidade se alinhasse ao projeto de industrialização de criação do órgão federal. Oliveira (2005, p. 62) complementa afirmando que a FUNDACT batizou toda a ação do prefeito Newton Rique.

No decênio de 1960, Campina Grande colhia os frutos de um plano de urbanização e do estilo arquitetônico moderno que já havia se consolidado em Campina Grande. 0 progresso era notório e a arquitetura moderna imperava as novas construções da cidade: o Teatro Municipal Severino Cabral que em seu projeto original era todo na cor branca, a Escola Politécnica da Universidade da Paraíba em branco, concreto armado e tijolo aparente; e as residências suntuosas de médicos e comerciantes marcaram a história de Campina, pautada em emergência no avanço civil e tecnológico (Figura 8).
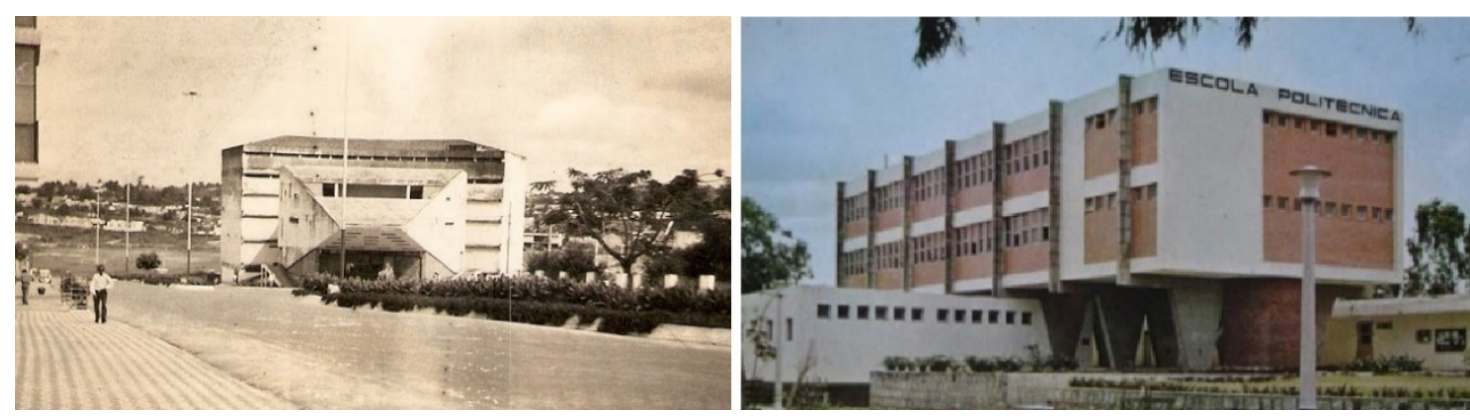

Figura 8. Teatro Municipal Severino Cabral e Escola Politécnica da Universidade da Paraíba. Foto: Acervo Josemar Pontes do Ó e arquivo da UFCG

A arquitetura moderna campinense incorporou características provenientes da Escola do Recife, como afirma Afonso e Meneses (2015, p. 5) que, devido Campina Grande ter sido, na época, um grande centro econômico e por sua proximidade com a capital pernambucana, os arquitetos formados em Recife se beneficiaram do fato de existirem poucos arquitetos residentes em Campina Grande e de uma elite que estava atenta ao que era produzido em Pernambuco, assim, encontrando em Campina um interessante campo de trabalho.

Assim, houve algumas características peculiares do conjunto arquitetônico moderno da cidade: linhas funcionais, valorização da climatização natural e predominância volumétrica. Outra especificidade da modernidade campinense era os revestimentos variados que formavam a execução das obras: módulos vazados, cerâmicas, ladrilhos hidráulicos, azulejos e tacos compunham os pisos e paredes.

Alguns desses revestimentos permanecem nas residências modernas campinenses, a exemplo da Residência Antônio Diniz Magalhães (Figura 9) e da Residência Feliciano Alexandre Ferreira (Figu- 
ra 10), projetadas por Geraldino Duda, expressando um passado não tão distante, permanecendo nas construções e deixando um legado para o conjunto arquitetônico moderno da cidade.

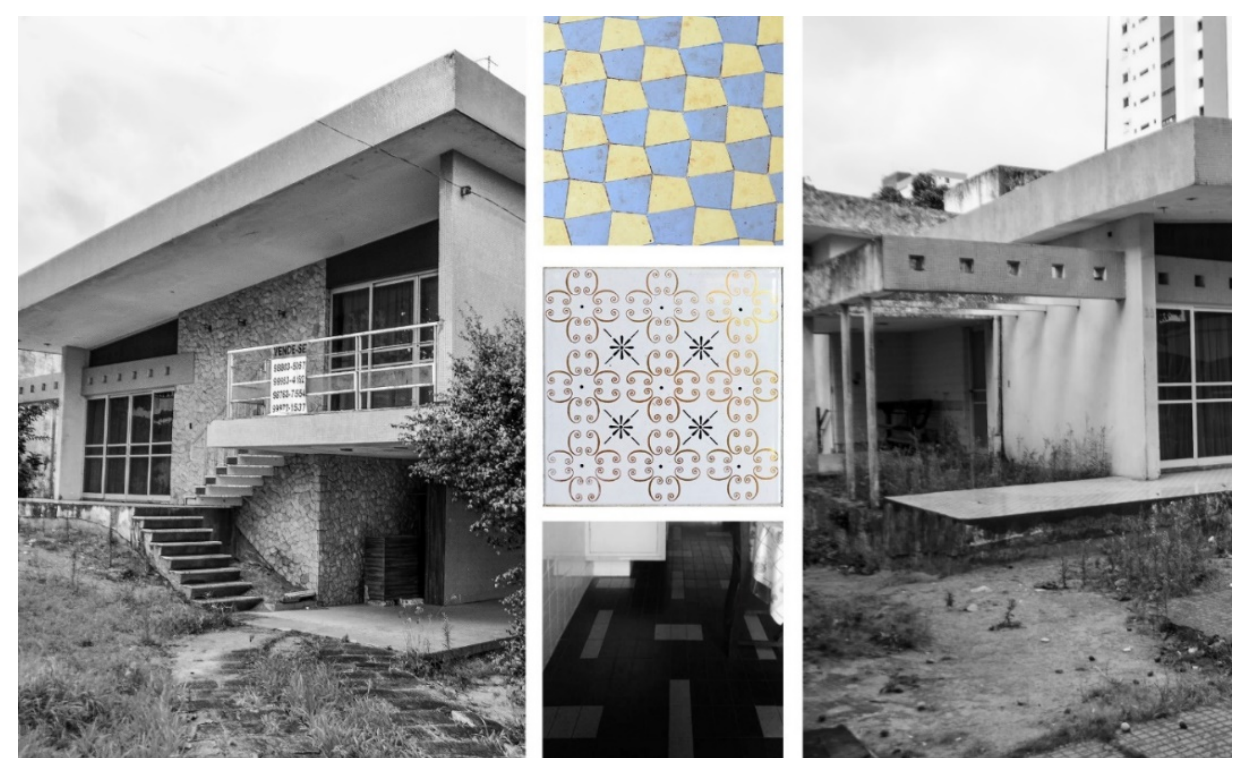

Figura 9. Residência Antônio Diniz Magalhães e sua situação atual. Elaborado pelo autor.
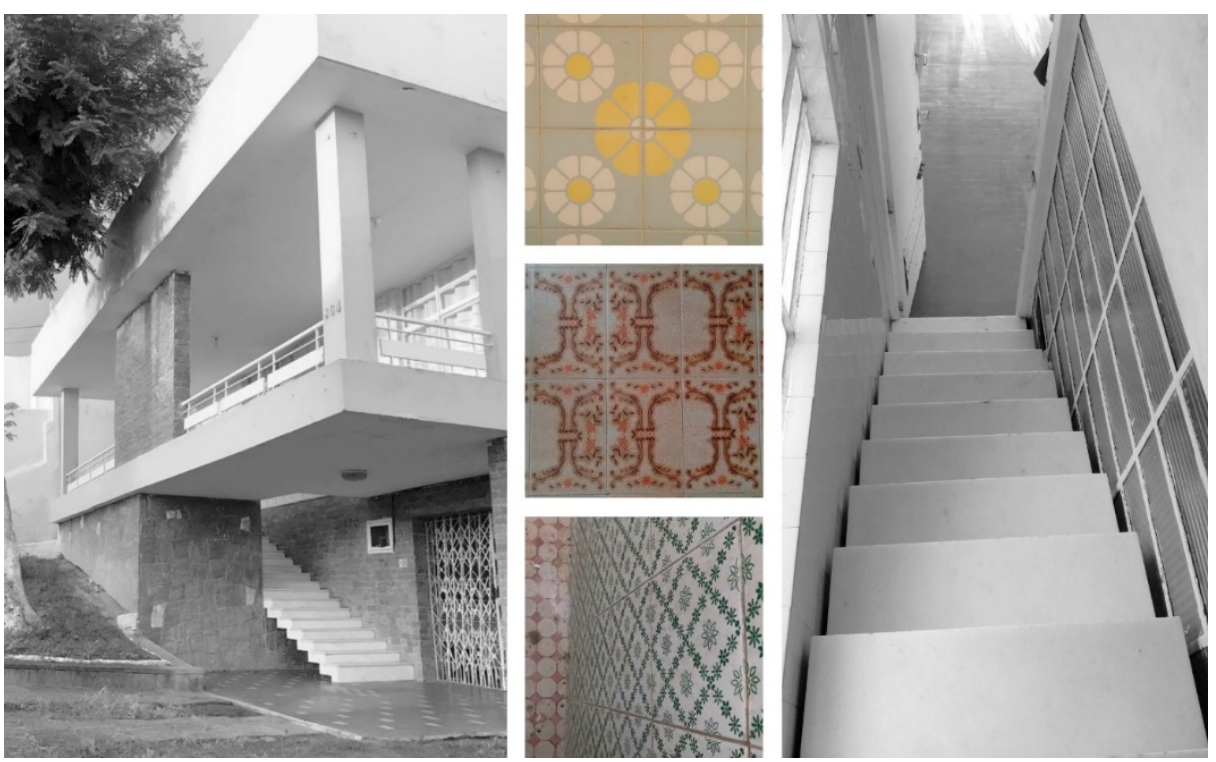

Figura 10. Residência Feliciano Alexandre Ferreira e sua situação atual. Elaborado por GRUPAL em 2018.

Ao contrário do que era utilizado nas construções modernas de Brasília, Rio de Janeiro e São Paulo, onde os azulejos de Athos Bulcão revestiam as paredes dos palacetes e residências opulentas, em alternativa a estas placas cerâmicas, Geraldino Duda aplicava em seus painéis o ladrilho hidráulico produzido localmente (Figura 11).

Figura 11. Painel do jardim da Residência Helion Paiva projetada em 1968 Elaborado pelo autor.

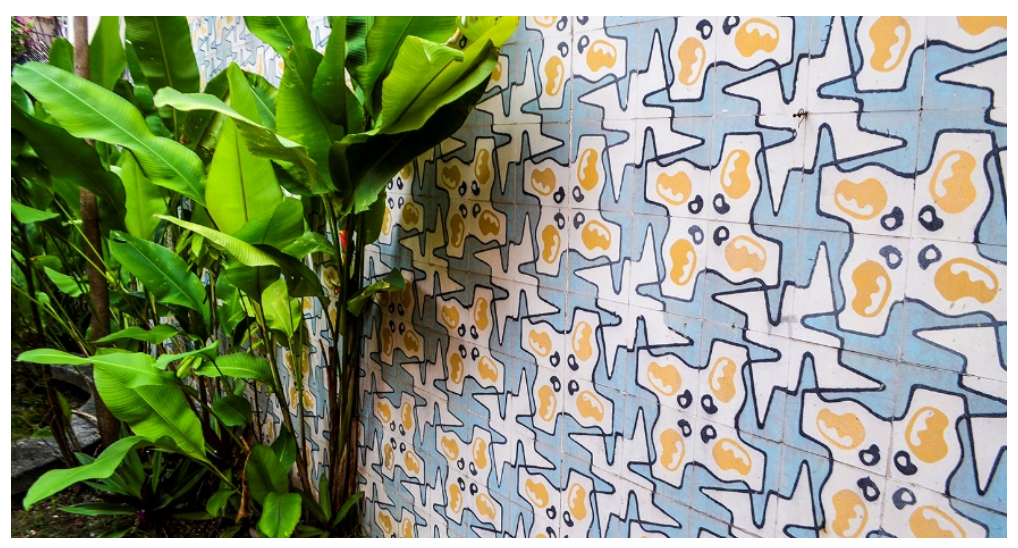


Esta constatação baseada nas pesquisas realizadas pelo GRUPAL (Grupo de Pesquisa Arquitetura e Lugar) ${ }^{1}$, ao coletar as residências projetadas pelo arquiteto Geraldino Duda através de registro fotográfico, comprovou-se o uso de ladrilho hidráulico em pisos e paredes. Na década de 1960, período de maior concentração de fábricas de mosaicos em Campina, Geraldino Duda projetou 46 residências unifamiliares, onde utilizava os desenhos já existentes, ou seja, ele não desenvolvia os padrões dos ladrilhos hidráulicos.

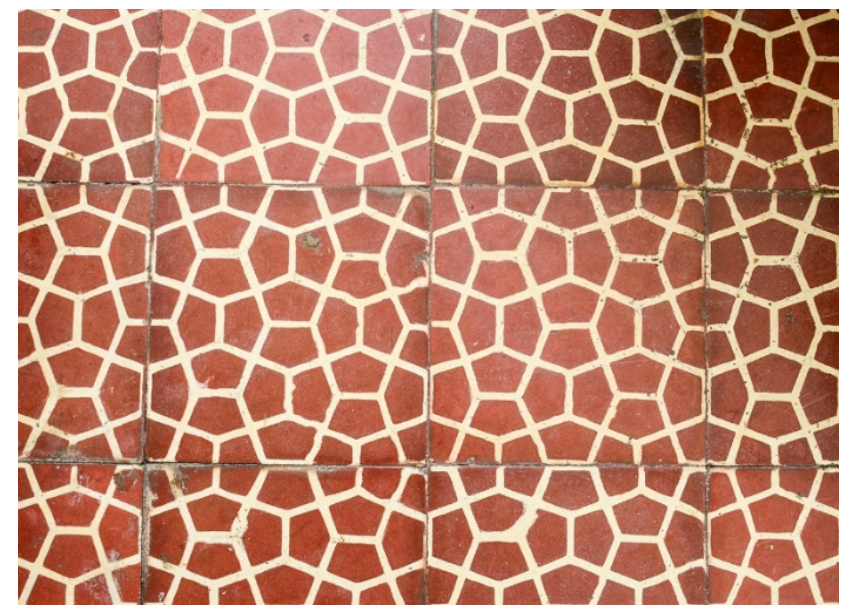

Figura 12. Piso do hall de entrada da Residência Otavio Lima Leite, projetada em 1962. Elaborado pelo autor.

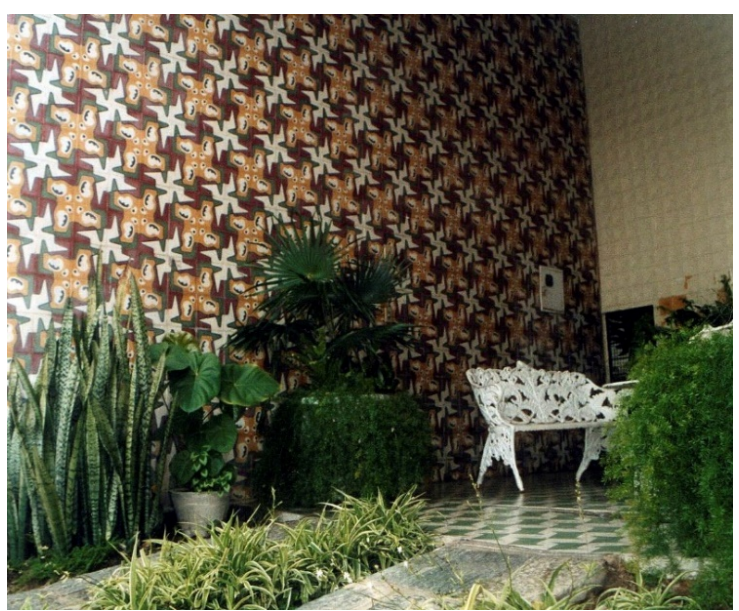

Figura 13. Terraço da residência com piso e parede de ladrilhos. Fonte: João Batista Guedes (arquivo pessoal).

É possível, que através de suas viagens para reconhecimento dos projetos de arquitetura moderna que se desenrolavam pelo Brasil, Geraldino Duda utilizou como referência o uso do ladrilho nas obras modernas, mesmo que de maneira sucinta e pontual, atraiu a atenção do arquiteto, engenheiro e artista Flávio de Carvalho, que projetou o conjunto de dezessete casas da Alameda Lorena (Figura 15), construídas em São Paulo entre 1936 e 1938, utilizando-se de aspectos comuns às suas obras ao preocupar-se com a redução das funções da casa, a higiene das habitações, o mobiliário adequado construído nos cômodos em alvenaria e ao utilizar ladrilho hidráulico no piso (Figura 14) para conforto térmico, com desenhos de sua autoria (Rossetti, 2007, p.156).

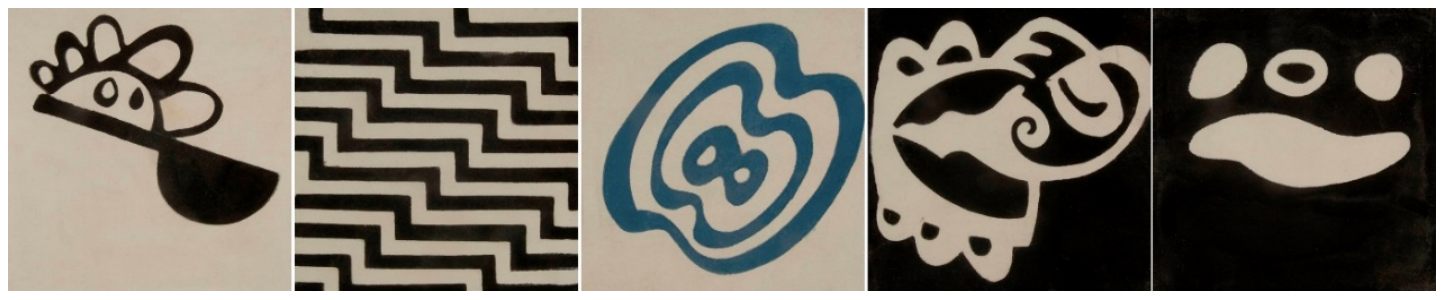

Figura 14. Ladrilhos desenhados por Flávio de Carvalho para as casas da Alameda Lorena. Fonte: arkpad.com

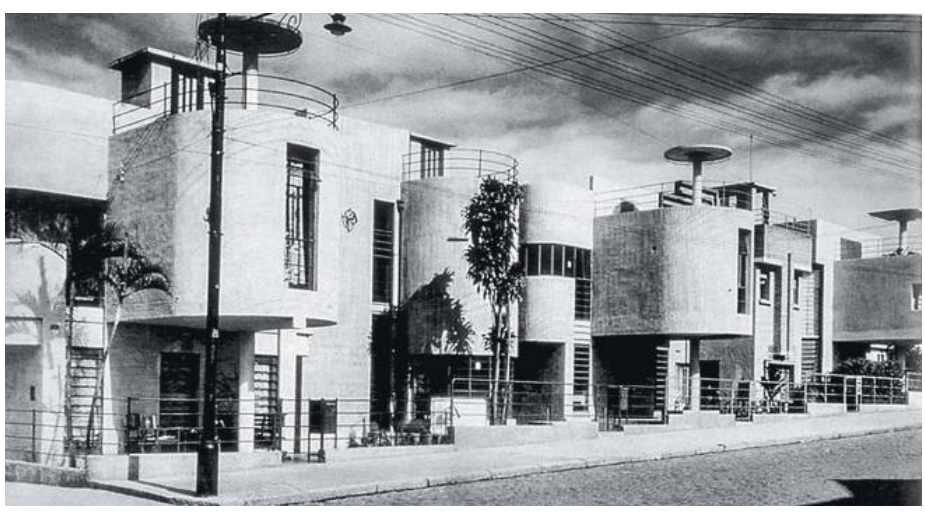

Figura 15. Casas da Alameda Lorena em São Paulo (1936-1938)

Fonte: Veja SP (on-line).

\footnotetext{
10 grupo de investigação Arquitetura e Lugar, cadastrado no CNPq, e vinculado ao curso de graduação em Arquitetura e Urbanismo da UFCG, e aos programas de Mestrado em Design da UFCG e de Artes, Patrimônio e Museologia da UFPIvem realizando junto a uma rede de pesquisadores, arquitetos, urbanistas, designers e historiadores, além de participar de rede internacional de pesquisas sobre a preservação do patrimônio industrial, o grupo INCUNA.
} 
Posteriormente, o arquiteto moderno Paulo Mendes da Rocha, o qual fazia parte da Escola Paulista de Arquitetura, movimento liderado por Vilanova Artigas na segunda metade do século XX, também utilizou ladrilho hidráulico no piso de uma de suas casas projetadas em 1968, a Residência Mario Masetti, em São Paulo (Acayaba, 2011, p. 286).
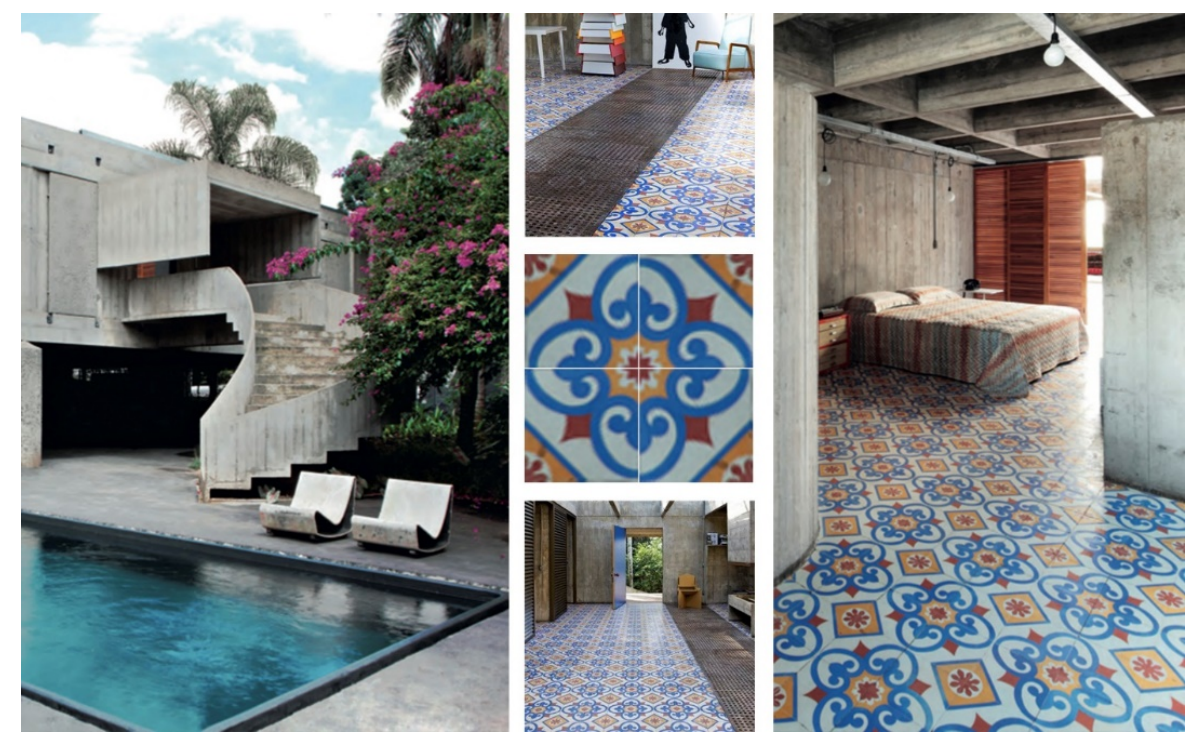

Figura 16. Residência Mario Masetti (1968): Paulo Mendes da Rocha. Fonte: arquivo.arq.br

A Residência Mario Masetti, por exemplo, de autoria de Paulo Mendes da Rocha, possui em seu piso um extenso tapete de ladrilhos hidráulicos (Figura 16). Porém, enquanto Paulo Mendes da Rocha e Flávio de Carvalho se limitou no uso do revestimento hidráulico somente no piso, Geraldino avançou, aplicando-os além do piso, também nas paredes, formando enormes painéis.

Prosseguindo para demais acontecimentos do decênio de 1960, quando o processo de industrialização tomou rumos fortes na década com o desenvolvimento econômico tendencioso a favor do sul e sudeste, Campina Grande perdeu espaço para o Centro-Sul do país, decaindo os investimentos em decorrência do abastecimento direto das cidades sertanejas do Estado que antes dependiam do mercado campinense.

Diante de todos os fatos expostos da década de 1960, acerca do auge da arquitetura moderna, é importante investigar a quantidade de fábricas de ladrilhos hidráulicos neste mesmo decênio. Pode-se observar que alguns fatores resultaram na eclosão deste segmento industrial:

O processo de industrialização de Campina Grande vem se acelerando em marcha crescente, desde que aqui se implantou o fornecimento da energia da CHESF, que eliminou completamente o problema que se constituia um dos obstaculos primordiais às industrias campinenses. Fatores diversos são favoráveis à atração de industrias para o municipio, entre os quais, segundo a Federação das Industrias de São Paulo (FIESP) no Livro "São Paulo e a Economia Nordestina" da Coleção "o Pensamento da Industria", os seguintes: a) Situação privilegiada no interior do Nordeste com relativa equidistância dos núcleos econômicos mais vivos da região; b) cidade bem servida por meios de transporte; c) baixo salário mínimo; d) variedade de matérias-primas vegetais, animais e minerais: algodão, agave, óleos, leite, couro e peles, minerais não-metálicos, etc; e) Mercado regional em fase de expansão; f) facilidades oferecidas, quer pela municipalidade, quer pelo governo do Estado e pela União, visando a instalação de novas industrias; g) Facilidade de aquisição de áreas para localização de novas indústrias (PMCG, 1964, p 13).

Diante do efetivo crescimento do setor industrial, a partir da década de 1960, a FIEP iniciou a publicação dos cadastros industriais como forma de regularizar e registrar as indústrias de todo o Estado. No total, foram publicados seis cadastros industriais. Os dados da primeira edição, lançada em 1969, foram obtidos diretamente com os empresários através de entrevistas.

Seguindo um espaço de tempo de cinco em cinco anos, foram lançados os demais em 1974, 1979 e 1984. Esse intervalo quinquênio era "o mais apropriado, para os fins a que se destina o amplo 
levantamento das indústrias do Estado" (FIEP, 1985, p. 5), ou seja, era o tempo necessário para obter mais dados atualizados para uma próxima edição.

Já as últimas edições, lançadas em 1992 e 1997 não seguiram o mesmo intervalo quinquênio. Segundo a FIEP (1992, p. 5), a delonga na produção das últimas edições foi devido a fatores conjunturais diversos, como períodos difíceis pela situação recessiva financeiramente, o que fez diminuir o progresso econômico do Nordeste e afetando principalmente a indústria da construção civil, fato que prejudicou diretamente as fábricas de LH de Campina Grande.

A partir do último cadastro impresso de 1997, a FIEP informatizou os dados e, até então, utiliza uma plataforma online onde todos os cadastros das indústrias da Paraíba são disponibilizados no site oficial da instituição.

Nos cadastros, a divisão era feita em quatro partes: a primeira com a relação das indústrias por ordem alfabética dos municípios; a segunda, com a relação das indústrias por ordem alfabética das razões sociais; a terceira, com a relação das indústrias por ramo de atividade industrial; e por último, a quarta, com a relação de todos os municípios com o número de industrias existentes em cada um. Para o cadastro das empresas, não havia restrição ao capital aplicado ou o número de operários.

Segundo dados dos Cadastros Industriais do Estado da Paraíba (FIEP, 1969), na década de 1960 existiram seis fábricas produtoras de ladrilho hidráulico em Campina Grande (Ver tabela 1).

Tabela 1. Quadro com os dados das fábricas de LH de Campina Grande da década de 1960.

\begin{tabular}{|c|c|c|c|c|}
\hline & ENDEREÇO & CAPITAL INICIAL & FUNDAÇĀO & LINHA DE PRODUÇĀO \\
\hline $\begin{array}{l}\text { Antônio Guedes } \\
\text { de Andrade }\end{array}$ & $\begin{array}{l}\text { Rua Rodrigues Alves } \\
\text { - Prata }\end{array}$ & Ncr\$ 500,00 - Op.: 2 & 1947 & $\begin{array}{l}\text { Fabricação de mosaicos } \\
\text { e combogóss }\end{array}$ \\
\hline $\begin{array}{l}\text { Edson Barbosa } \\
\text { de Lima \& CIA LTDA }\end{array}$ & $\begin{array}{l}\text { Rua Antenor Navarro, } \\
1232 \text { - Centro }\end{array}$ & NCr\$ 9.500,00 - Op.: 11 & 1960 & Fabricação de mosaicos \\
\hline Waldemar Brito & $\begin{array}{l}\text { Av. Aprígio Veloso, } \\
171 \text { - Bodocongó }\end{array}$ & NCr\$ 5.000,00 - Op.: 6 & 1963 & Fabricação de mosaicos \\
\hline $\begin{array}{l}\text { Antônio Honório } \\
\text { Sobrinho }\end{array}$ & $\begin{array}{l}\text { Rua Silva Barbosa, } \\
1107 \text { - Bodocongó }\end{array}$ & NCr\$ 5.000,00 - Op.: 2 & 1966 & Fabricação de mosaicos \\
\hline $\begin{array}{l}\text { Deoclecio Bezerra } \\
\text { da Silva }\end{array}$ & $\begin{array}{l}\text { Rua João Pessoa, } \\
728 \text { - Centro }\end{array}$ & NCrS 1.000,00 - Op.: 4 & 1967 & Fabricação de mosaicos \\
\hline $\begin{array}{l}\text { Maria dos Prazeres } \\
\text { Andrade }\end{array}$ & $\begin{array}{l}\text { Av. Aprígio Veloso, } \\
246 \text { - Bodocongó }\end{array}$ & NCrS 1.000,00 - Op.: 1 & 1967 & Fabricação de mosaicos \\
\hline
\end{tabular}

Alguns fatores certamente conspiraram para a instalação acelerada das fábricas no município, como a demanda oriunda de uma necessidade de higienização e impermeabilização das superfícies das construções campinenses, na qual o chão batido e o cimento queimado não se enquadravam.

Analisando o fator econômico, houve uma fomentação no surgimento das indústrias de ladrilho hidráulico em Campina Grande. Como afirmam Queiroz e Rocha (2007, pp. 1-2): o município que, envolvido por uma atmosfera de otimismo e mudanças que permeavam o imaginário da população, a partir dos anos 1960, a cidade experimentava o "desenrolar de um novo ciclo de modernização, em compasso com os acontecimentos nacionais e alicerçados nos esforços da elite local para inserila no processo de industrialização do país".

Assim sendo, investigando o fator tectônico ${ }^{2}$, houve o uso de ladrilhos hidráulicos na arquitetura moderna campinense em alternativa ao uso do azulejo, devido à facilidade na obtenção da matéria-

\footnotetext{
2 Sobre o conceito do que é tectônica na arquitetura, Amaral (2009, p. 148-167) explica que se trata do conjunto de elementos, técnicas e materiais relacionados ao potencial de expressão construtiva. Também considerada como uma "poética da construção", a tectônica seria capaz de reunir os aspectos materiais da arquitetura aos aspectos culturais e estéticos. A autora ainda afirma que, depois dos gregos, o termo "tectônica" foi retomado no círculo alemão do século 19 como forma de explicar a arquitetura em sua relação à construção. De acordo com Georg Germann, "a noção de tectônica formou-se, indubitavelmente, no pensamento do arquiteto e teórico Karl Friedrich Schinkel (1781-1841) e no seu ambiente berlinense por volta de 1830"
} 
prima produzida localmente, havendo uma valorização do revestimento e sua disseminação na ornamentação das construções modernas.

A prova de que o segmento de fabricação dos ladrilhos hidráulicos era forte na cidade foi a exposição do Stand da Fábrica de Edson Barbosa de Lima \& Cia. Ltda. na Feira da Indústria de Campina Grande que aconteceu entre os dias 9 a 16 de outubro de 1965 sob o patrocínio da Prefeitura Municipal (perante o comando administrativo do Prefeito Williams Arruda), através da Secretaria de Economia e da CINGRA (Companhia de Industrialização de Campina Grande), promovida e organizada por Empreendimentos Borborema S.A. (CINGRA, 1965).

Sem fins lucrativos, a feira realizada no pavilhão do Clube do Trabalhador 3 , visava apenas expor uma amostra do que se fabricava na cidade, promovendo os produtos industriais e incentivando a produção local a fim de atrair novos investimentos para o município.

Inclusive, a SUDENE teve um papel importante na abertura de indústrias locais, beneficiando uma das fábricas de ladrilho e cobogós instalada neste decênio (Alves, 2012, p 84).

Sobre a importância da SUDENE e CINGRA no desenvolvimento industrial e na economia local, em 1968, o Banco do Nordeste do Brasil publicou junto com o Departamento de Estudos Econômicos do Nordeste (ETENE) um balanço sobre o consumo de produtos industriais na cidade de Campina Grande:

O Estado da Paraíba possui dois Distritos Industriais e um deles é localizado em Campina Grande, razão de incentivo para a criação de novas industrias. Em levantamento realizado pela SUDENE em 1965, Campina Grande foi classificada em 4 lugar entre as cinco cidades nordestinas mais beneficiadas com implantação ou ampliação de fábricas, superando, inclusive, as capitais de Estados da Região, exceto Recife, Salvador e Fortaleza (BNB, 1968, p.10).

Foi Edvaldo de Souza do Ó, reitor, professor e economista, em parceria com o então Prefeito Williams Arruda, que criou a CINGRA, primeira Companhia de Industrialização de Campina Grande e de todo o Estado (Oliveira, 2005, p.10). Edvaldo do Ó foi presidente da Companhia de 1964 à 1966, fomentando o desenvolvimento econômico e assessorando o governo municipal na elaboração de vários projetos setoriais:

[...] Além dos incentivos fiscais da SUDENE, Campina Grande conta com um instrumento financeiro, a Companhia de Industrialização de Campina Grande - CINGRA, sociedade de economia mista com participação majoritária do Município, que tem como finalidade gerir o Fundo Municipal de Industrialização --FUMINGRA. Este consiste de recursos destinados a atender às necessidades de financiamento do processo industrial redirecionando meios para ampliação e implantação de unidades industriais (BNB, 1968, p.10).

Assim, a CINGRA, que tinha sua sede em Campina Grande localizada na Av. Marechal Floriano, 89 - 1o andar, certamente inspirou a criação da CINEP, antes denominada de Companhia de Industrialização do Estado da Paraíba, com mesmo objetivo, mesma linha de ação e operando no âmbito estadual (CINGRA, 1966).

Dados da PMCG (1964, p 10) afirmam que Campina Grande possuía cerca de 636 estabelecimentos industriais que empregavam, aproximadamente, 15.000 operários. $50 \%$ destes estabelecimentos eram pequenas indústrias que, geralmente, ocupavam menos de 10 operários. As empresas de médio porte, que era o caso da Fábrica Resistência, onde segundo o livro de registros, consta o seu termo de abertura, anexada à Junta Comercial do Estado da Paraíba, na qual possuía 14 empregados.

Em 1966, houve um estudo de viabilidade para implantação de uma indústria de azulejos em Campina Grande apoiado pela SUDENE, Governo do Estado e convênio com a Universidade Federal da Paraíba, o chamado "Projeto Uniplas" (que fez parte do Programa Universitário de Desen-

30 Clube do Trabalhador Aprígio Velloso, localizado à Rua Dom Pedro II, 767, no Bairro da Prata em Campina Grande foi projetado pelo arquiteto moderno Tertuliano Dionísio da Silva. 
volvimento Industrial da UFPB) que enxergou, na época, que não havia produção local de artigos derivados do Caulin, sabendo que a matéria-prima já existia em abundância em distritos próximos (FIEP, 1966).

O projeto não foi implantado, devido aos grandes concorrentes deterem boa parte deste mercado: a Cerâmica São José e a Indústria de Azulejos S.A. (IASA), ambas de Recife [PE]. Entretanto, este fato mostra que os revestimentos cerâmicos já estavam em ascensão, culminando no declínio do uso dos ladrilhos hidráulicos.

Assim, observou-se que a década de 1960 foi um período efervescente para o setor industrial, com abertura de novas fábricas e fomentação na criação de novas indústrias, devido às iniciativas públicas e ao mercado em ascensão.

Seguindo para a década de 1970, houve uma recessão das indústrias de ladrilho hidráulico e ascensão de outros setores industriais. Da primeira edição do Cadastro Industrial do Estado da Paraíba, lançada em dezembro de 1969, até agosto de 1974 (mês de lançamento da edição dos anos 1970) houve uma recessão no número de fábricas de ladrilho hidráulico.

Na década em questão, nos Cadastros Industriais do Estado da Paraíba (FIEP, 1974) e no Cadastro das Empresas Industriais do Estado da Paraíba (CEBRAE, 1973), consta que só existiam três fábricas de ladrilhos, uma delas não informada no cadastro anterior de 1969 (Ver Tabela 2).

Tabela 2. Quadro com os dados das fábricas de LH de Campina Grande da década de 1970.

\begin{tabular}{|c|c|c|c|c|}
\hline & ENDEREÇO & CAPITAL INICIAL & FUNDAÇÃO & LINHA DE PRODUÇĀO \\
\hline $\begin{array}{l}\text { Antônio Guedes } \\
\text { de Andrade }\end{array}$ & $\begin{array}{l}\text { Rua Rodrigues Alves } \\
\text { - Prata }\end{array}$ & Ncr\$ 500,00 - Op.: 2 & 1947 & $\begin{array}{l}\text { Fabricação de mosaicos } \\
\text { e combogóss }\end{array}$ \\
\hline $\begin{array}{l}\text { Edson Barbosa } \\
\text { de Lima }\end{array}$ & $\begin{array}{l}\text { Rua João Pessoa, } \\
729 \text { - Centro }\end{array}$ & Cr\$ $13.000,00$ & 1970 & $\begin{array}{l}\text { Fabricação de mosaicos, } \\
\text { marmorites e cobogós }\end{array}$ \\
\hline $\begin{array}{l}\text { América dos Santos } \\
\text { Sobrinho }\end{array}$ & $\begin{array}{l}\text { Rua Arrojado Lisboa, } \\
550 \text { - Centro }\end{array}$ & - & 1973 & Fabricação de mosaicos \\
\hline
\end{tabular}

Fonte: FIEP (1974).

Fundou-se, então, por América Sobrinho, mais uma nova fábrica de ladrilhos na cidade. Antônio Guedes de Andrade continuou com seu empreendimento. Já Edson Barbosa de Lima que manteve durante dez anos a sociedade empresarial com seus familiares Emilio Barbosa de Lima e Jonas de Oliveira, a partir de 1970, começou a dirigir os negócios isoladamente em novo endereço, na Rua João Pessoa, 729 - Centro.

Adentrando no decênio de 1980, o período foi marcado pelo desuso dos ladrilhos hidráulicos e instabilidade econômica no setor industrial. Inegavelmente, houve vários motivos que levaram ao fechamento das indústrias que funcionaram na década de 1970 e que porventura encerraram suas atividades na década seguinte, dentre eles, a falta de incentivos fiscais e dificuldade na abertura de crédito para pequenas empresas.

Nas décadas anteriores, tem-se registrado nos Cadastros Industriais da FIEP a instalação de várias fábricas de ladrilhos em Campina, enquanto estas mesmas, por motivos diversos, encerraram suas atividades. Segundo Agostinho Velloso da Silveira, alguns fatores descritos a seguir devem ser ressaltados como possíveis motivos que ocorreram a partir de 1980 em diante (FIEP, 1985).

Primeiramente, um longo período de secas no Nordeste durante quase 5 anos, assolando principalmente o Estado da Paraíba. O segundo motivo, tratou-se de uma política econômica de índole recessiva, em face de fatores decorrentes do endividamento externo a exigir enorme esforço de produção e exportação do País para o pagamento do serviço da dívida e do agravamento do déficit público interno de recursos para promover o desenvolvimento econômico e, dentro deste, o industrial de modo particular. 0 terceiro motivo, foram as modificações restritivas nos critérios de incentivos à industrialização que, no decênio anterior, ainda recebia substancial ajuda financeira através da SUDENE - a principal agência de desenvolvimento do Governo Federal na região. 
O quarto e último motivo, ocorreu devido as prioridades governamentais para empreendimentos de grande porte em outras regiões do País (hidrelétrica de Itaipu no Sul, Projeto Carajás - Tucuruí no Norte, programa siderúrgico no Sudeste), que exigiram grandes aportes de recursos federais que impossibilitaram a continuação dos programas específicos de desenvolvimento da região nordestina nos moldes em que o mesmo vinha sendo comandado pela SUDENE.

Assim, o Estado da Paraíba sofreu muito em sua economia durante este período. Desorganizouse a sua tradicional e relativamente forte economia agrícola. Reduziu-se seu desenvolvimento industrial, principalmente naqueles empreendimentos que ainda não haviam atingido a fase de plena maturação, como era o caso das fábricas de ladrilhos hidráulicos.

Sobre o processo de recessão industrial de Campina Grande, Sá (2000) descreve que a partir da década de 1970 acentuou-se o crescimento da industrialização em benefício das capitais com o intuito de fortalecer suas funções político-administrativas e comerciais, transformando-as em grandes centros distribuidores dos produtos industriais. Por isso, Campina registrou entre as décadas de 1970-1980 um índice de crescimento de 28,1\%, caindo para 23,0\% entre 1980-1990, enquanto João Pessoa apresentou um índice crescente de 40,0\% no mesmo período.

De certo, um fator decisivo para o desuso dos ladrilhos hidráulicos, não somente em Campina Grande, mas em todo o Brasil, foi a ascensão dos pisos cerâmicos mais baratos com superfície esmaltada, ausentes de manutenção sem a necessidade de aplicar ceras para lustrar ou impermeabilizar, sem falhas visuais e com linha de produção automatizada para fabricação em larga escala, afetando a fabricação dos ladrilhos que não tinham como competir em produtividade.

Partindo para o último decênio do recorte temporal da pesquisa, após o fechamento de todas as fábricas de ladrilho hidráulico que ocorreu entre 1970-1980, Campina Grande iniciou os anos de 1990 sem registro de indústrias do segmento, até o ressurgimento da Fábrica Metro Materiais.

\section{A origem da Fábrica Metro Materiais}

Os primórdios da Fábrica Metro iniciaram-se em 1947, com o nome fantasia de Fábrica de Mosaicos Resistência, sendo a pioneira do segmento na cidade (Figura 17). O Proprietário e fundador, Antônio Guedes de Andrade, que sempre manteve um espírito empreendedor, nasceu no dia 27 de setembro de 1906, em Brejo do Cruz, interior da Paraíba (Dinoá, 1993, p.128).
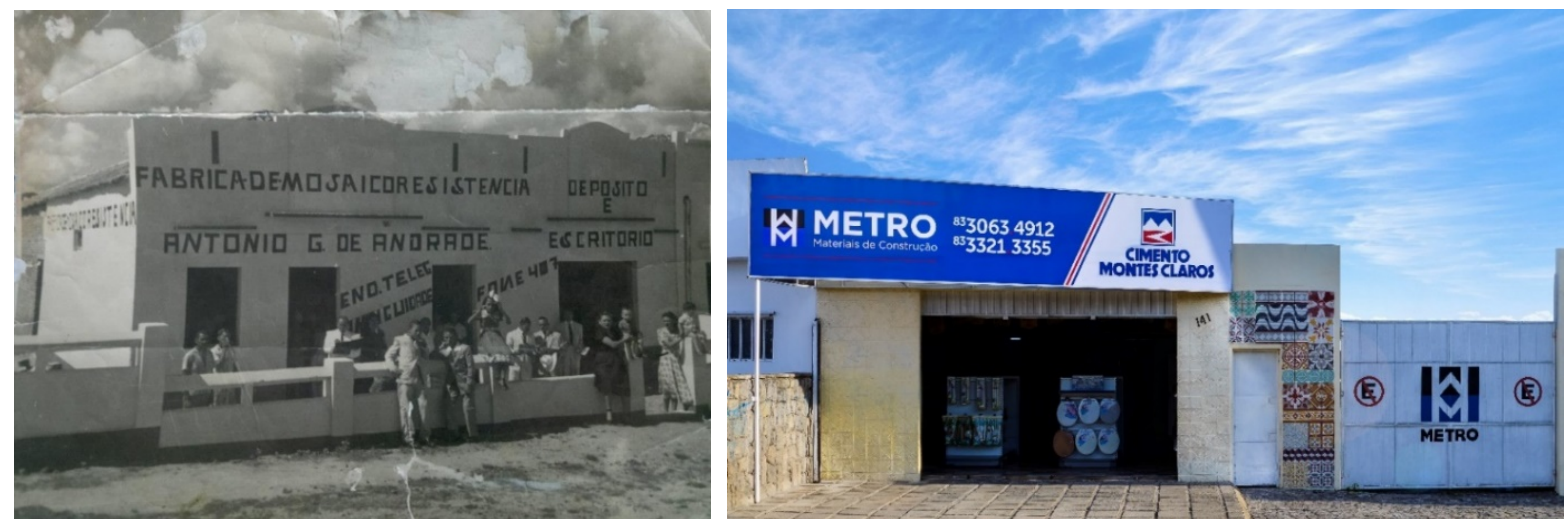

Figura 17. Antiga Fábrica de Mosaicos Resistência e atual Metro Materiais. Fonte: arquivo pessoal da Metro Materiais.

Com o encerramento das atividades da Fábrica de Mosaicos Resistência em 1989, Campina Grande permaneceu cinco anos sem indústrias do segmento. Com isso, visando à reinserção dos ladrilhos nos projetos de arquitetos e designers em todo o Brasil, Januário Ferreira de Sousa Neto (neto de Antônio Guedes de Andrade) herdou todo o legado do avô, que após cinco anos de inatividade, retomou a tradição familiar em 1995.

Na medida em que as fábricas de mosaicos que existiam na cidade iam encerrando suas atividades, acabavam repassando e revendendo seu maquinário, ferramentas e matrizes para as 
fábricas que ainda se mantinham no mercado. Como a Metro tem sido a única do Estado no segmento, ela detém grande parte das matrizes e máquinas das demais.

Tudo isto se tornou um ponto de partida para o desenvolvimento de um inventário visual formado pelos registros dos padrões de matrizes dos ladrilhos coletados na fábrica, algumas já em estado de deterioração. Por ser uma indústria rústica de pequeno porte, não existe um catálogo disponível com todos os exemplares existentes na fábrica.

\subsection{Mapeamento do processo produtivo da Fábrica Metro Materiais}

A produção do ladrilho hidráulico está diretamente ligada ao cimento Portland. A norma da ABNT NBR 9457, exige a utilização do cimento branco ou Portland CP 320 ou superior na fabricação dos LH (Figura 18).

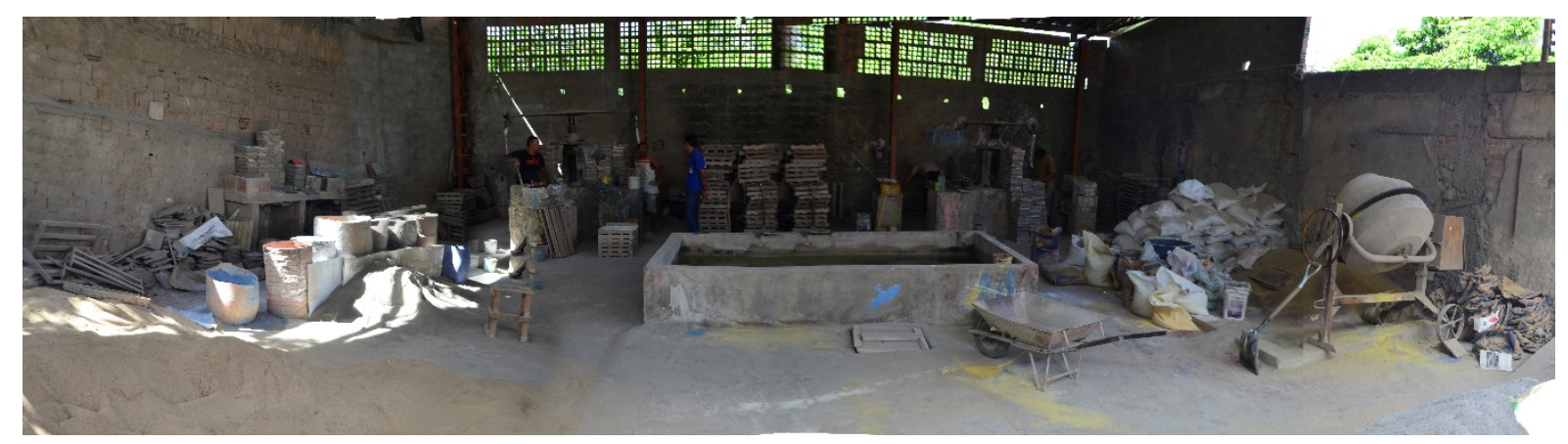

Figura 18. Imagem panorâmica do setor de produção da Fábrica Metro. Fonte: Medeiros (2018)

Além dos tipos de cimento, o LH possui em sua composição agregados com granulometria das peneiras no 40 a 80 . Também é utilizado a areia de pedra seca (chamado também "pó de pedra"). Na massa pigmentada são adicionados pigmentos inorgânicos. A água, que atua no final do processo de fabricação, é um importante mecanismo de hidratação do cimento Portland.

Prosseguindo para as etapas do processo de fabricação da Metro, além do registro fotográfico, foram realizadas diversas visitas objetivando conhecer a técnica tradicional utilizada na produção e, a partir disso, realizar o mapeamento necessário para o desenvolvimento das análises (Figura 19).

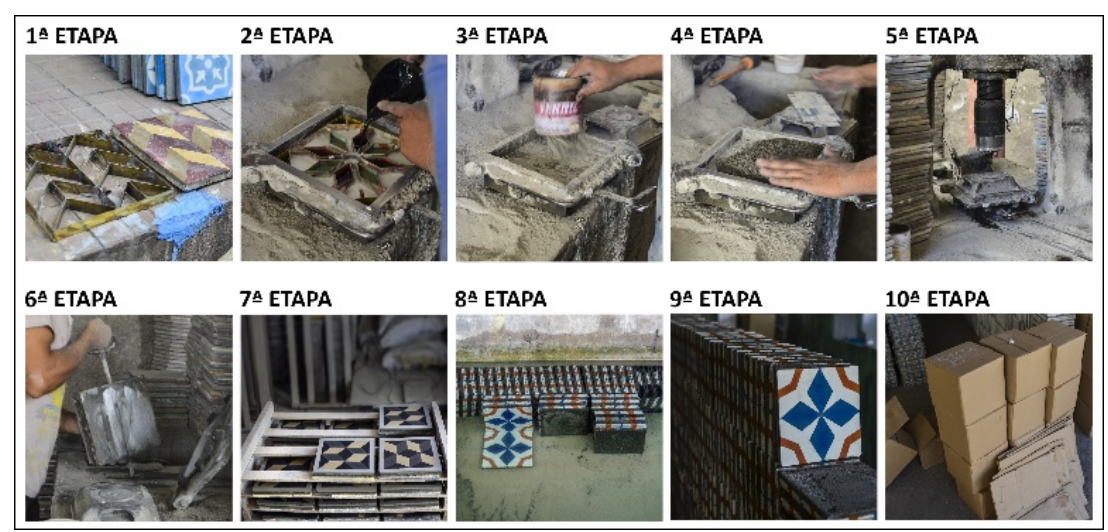

Figura 19. Etapas do processo de fabricação do LH. Fonte: elaborado pelo autor (2018).

Assim, as etapas do processo são: $1^{\underline{a}}$ etapa - Escolha da forma e molde de ferro de acordo com o tipo de revestimento desejado; $2^{\underline{a}}$ etapa - Utilização de fôrma (matriz) com molde (esquadro de ferro) para despejo da massa pigmentada; $3^{\underline{a}}$ etapa - Retirada do molde e a camada de tinta recebe uma porção de cimento seco que elimina o excesso de água; $4^{a}$ etapa - Colocação da

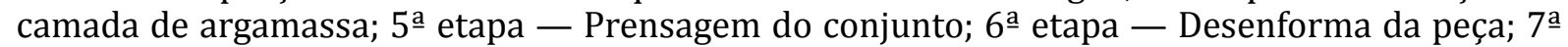
etapa - Repouso do material por 12 horas; 8a etapa - Imersão dos ladrilhos por cerca de oito horas após o repouso; 9a etapa - Secagem das peças de forma natural por cerca de vinte dias após o tempo de imersão; $10^{\mathfrak{a}}$ etapa - Acondicionamento. 


\section{Discussões e conclusões}

A partir dos dados apresentados, buscou-se refletir acerca das inquirições levantadas durante a pesquisa. Houve um direcionamento na pesquisa objetivando o registro técnica do processo de fabricação do produto e o percurso histórico das fábricas de ladrilho hidráulico que funcionaram em Campina Grande.

Dessa forma, a pesquisa buscou uma conscientização na área de educação patrimonial para sensibilizar os diversos atores da nossa sociedade para uma mobilização na luta pela preservação do patrimônio histórico e industrial, no intuito da sua requalificação.

O Grupo de pesquisas Arquitetura e Lugar, cadastrado na UFCG e no CNPq, vinculado ao curso de graduação em Arquitetura e Urbanismo da UFCG vem mantendo uma rede de intercâmbios e participando de eventos na área organizados pelo INCUNA Espanha, Cuba e pelo TICCIH, colaborando com a coleta de informações para a construção dos inventários industriais latino-americanos, desenvolvendo pesquisas sobre o acervo do patrimônio industrial campinense, investigando as relações históricas, sociais, econômicas e políticas que dialogam entre si.

Assim, deve-se situar o modo de produção da Fábrica Metro definindo-o como uma herança ao design de produto, fazendo-se necessário sua salvaguarda, conservação e definição de formas de permanência daquilo que se transformou em patrimônio industrial. Ao mesmo tempo em que a Metro se trata de um lugar de trabalho, também se torna um espaço de memória.

No decorrer da pesquisa, além das questões que permeiam sobre a trajetória das fábricas de ladrilho hidráulico de Campina Grande e sua técnica de fabrico, analisou-se, também, as diversas fases do uso desse revestimento a partir da década de 1940, o desuso e a reinserção em um dado período de mais de meio século.

Alguns fatores devem ser expostos na contribuição para o desuso dos ladrilhos hidráulicos: o declínio na qualidade visual e estética e o alto custo final do produto se comparado com os revestimentos cerâmicos que são fabricados rapidamente, eliminando o extenso prazo de entrega do ladrilho hidráulico.

Outro fator a ser levado em consideração trata-se da mecanização do setor de revestimentos cerâmicos fortalecida pela tecnologia para a produção em larga escala, que tornou possível a substituição sistemática dos ladrilhos hidráulicos. A disponibilidade no mercado dos pisos de cerâmica em grande quantidade e baixo custo, estimulado pelas propagandas incentivadoras da compra pela praticidade, manutenção e facilidade na limpeza.

Essa mesma tecnologia que possibilita a impressão em High Definition de simulacros dos ladrilhos, recria subterfúgios determinados ao consumidor, produzindo efeito ilusório e escondendo de quem os adquire, em alguns casos, a baixa qualidade, durabilidade inferior e o caráter módico de cópias inferiores.

Porcelanatos que imitam ladrilhos não respeitam as mesmas normas técnicas brasileiras que regem o ladrilho hidráulico e não possuem a mesma durabilidade. 0 apelo pode ser bastante interessante do ponto de vista financeiro, mas trata-se de um fato generalizador que precisa ser combatido pela sociedade.

Diante dos fatos expostos em relação às motivações que levaram a substituição do ladrilho hidráulico, investigou-se vários fatores que os reinseriram no mercado. Data-se no final do século XX quando os arquitetos e designers voltam seus olhares aos ladrilhos hidráulicos, como forma de personalização dos projetos. As questões que permeiam a sua reinserção seguem pela busca à singularidade e suas características artesanais.

Embora os produtos fabricados em grande escala façam parte do dia-a-dia da sociedade contemporânea, a busca por artefatos que "contem história", vem se tornando uma tendência no design, ou seja, estamos vivendo em um período que marca o surgimento de atitudes conservacionistas 
e restauradoras para os monumentos e patrimônios históricos e culturais. Segundo Russo e Hekert (2008), algumas pessoas amam produtos que contém significado simbólico, buscam o consumo consciente das matérias primas e dão preferência a produtos produzidos localmente.

Outro fator positivo na reinserção do ladrilho hidráulico nos projetos arquitetônicos está relacionado com a possibilidade cromática de personalização do produto aliados as variadas composições formais que podem ser escolhidas pelas gravuras pré-existentes ou até mesmo a criação de desenhos autorais.

Assim, destaca-se que o presente trabalho apresenta através de seus resultados, uma provocação para futuras pesquisas no campo de investigação do ladrilho hidráulico como um ponto de partida para questões sobre o patrimônio industrial, a partir de investigações em fontes primárias e com isso, abrindo também discussões sobre as demais fábricas que funcionaram no Estado da Paraíba.

\section{Referências}

ABNT. (1986). NBR 9457. Ladrilho hidráulico. Rio de Janeiro.

Acayaba, M. M. (2011). Residências em São Paulo 1947-1975. RG fac-símile, São Paulo, Romano Guerra.

Afonso, A. (2017). O processo de industrialização na década de 1960 e as transformações da paisagem urbana do Bairro da Prata. Campina Grande. Barcelona: 8o Seminário Internacional de Investigação em Urbanismo. SIIU UPC/ETSAB.

Afonso, A., \& Carvalho, J. (2015). Patrimônio industrial e território: Campina Grande e seu entorno. Seminário Ibero-americano Arquitetura e Documentação, 4. Anais. Belo Horizonte: UFMG.

Afonso, A., \& Meneses, C. (2015). A Influência da escola do recife na arquitetura de Campina Grande 1950-1970. Seminário Ibero-americano Arquitetura e Documentação, 4. Anais. Belo Horizonte: UFMG.

Alves, L. da S. (2012). A industrialização incentivada do Nordeste e o caso Campina Grande - PB. 2012. 95 f. Dissertação (Mestrado), Desenvolvimento Regional, UEPB/UFCG, Campina Grande, PB, Brasil.

Amaral, I. (2009). Quase tudo que você queria saber sobre tectônica, mas tinha vergonha de perguntar. PÓS-: Revista do Programa de Pós-graduação em Arquitetura e Urbanismo da FAUUSP, São Paulo, 1(26), pp. 148-167, dez.

Amorim, L. (2000) A paisagem recriada: a sedução do progresso recria memória na demolição de patrimônio histórico. In: E. de Q. Gurjão. Imagens multifacetadas da história de Campina Grande (pp.1-22). Campina Grande: PMCG.

Campina Grande (1950). Anuário de Campina Grande: Comércio — Indústria - Profissão. Campina Grande: PMCG. Anual.

BNB. (1968). Consumo de produtos industriais na cidade de Campina Grande / Banco do Nordeste do Brasil. Fortaleza, BNB.

CEBRAE. (1973). Cadastro das Empresas Industriais do Estado da Paraíba. João Pessoa: NAIPB.

CINGRA. (1966). Campina Grande, Dados e Informações - Companhia de Industrialização de Campina Grande - CINGRA.

CINGRA. (1965). Feira da Industria de Campina Grande. Campina Grande: PMCG.

Dezen-Kempter, E. (2016). Patrimônio Industrial: em busca da sobrevivência. In: Simpósio Nacional de História, 2007, São Leopoldo. História e Multidisciplinaridade: territórios e deslocamentos. São Leopoldo [RS]: Unisinos, 2007. pp. 1-12. Recuperado de: < https://goo.gl/yQiQJ2 > . 
Dinoá, R. (1993). Memórias de Campina Grande. Campina Grande. Editoração Eletrônica. 2 v.

FIEP. (1966). Azulejos: estudo de viabilidade para implantação de uma indústria em Campina Grande. Campina Grande: UFPB.

FIEP. (1969). Cadastro Industrial do Estado da Paraíba.

FIEP. (1974). Cadastro Industrial do Estado da Paraíba.

FIEP. (1985). Cadastro Industrial do Estado da Paraíba.

FIEP. (1992). Cadastro Industrial do Estado da Paraíba.

FIEP. (1997). Cadastro Industrial do Estado da Paraíba.

Gil, A. C. (2008). Como elaborar projetos de pesquisa. 4.ed. São Paulo: Atlas.

IBGE. (2016). Histórico Campina Grande Paraíba - PB. Recuperado de: <http://ibge.gov.br/cidadesat/ painel/historico.php?codmun=250400\&search=paraiba|campina-grande|inphographics:-history<=>.

Macedo, F. (2013). A geometria do ladrilho hidráulico. Goiânia: Instituto Casa Brasil de Cultura.

Marques, J. de S. (2012). Estudo do processo de produção de ladrilhos hidráulicos visando à incorporação de resíduos sólidos. 2012. Dissertação (Mestrado), Engenharia de Edificações e Saneamento, Universidade Estadual de Londrina. Londrina, PR, Brasil.

Oliveira, M. J. S. (2005). Do discurso dos planos ao plano discurso: PDLI - Plano de Desenvolvimento Local Integrado de Campina Grande 1970-1976. 2005. Dissertação (Mestrado), Desenvolvimento Urbano, Universidade Federal de Pernambuco. Recife, PE, Brasil.

Oliveira, M. J. S. \& Rodrigues, J. E. (2009). Memorial FIEP: Seis décadas de ações transformadoras. Campina Grande: Gráfica Marcone.

Parahyba, Lei №. 140, de 4 de outubro de 1928. (1928). Código de Posturas Municipais, Parahyba.

PMCG. (1964). Resumo histórico e estatístico de Campina Grande: diga ao Brasil que Campina Grande é centenária. Assessoria de Imprensa da PMCG.

Queiroz, M. V. D. de \& Rocha, F. de M. D. (2007). Caminhos da arquitetura moderna em Campina Grande: emergência, difusão e a produção dos anos 1950. In: F. D. Moreira. Arquitetura Moderna no Norte e Nordeste do Brasil: universalidade e diversidade. Recife: Fasa.

Queiroz, M. V. D. de. (2016). Quem te vê não te conhece mais: arquitetura e cidade de Campina Grande em transformação (1930-1950). Campina Grande: EDUFCG.

Rossetti, C. P. (2007). Flávio de Carvalho: questões de arquitetura e urbanismo. Dissertação (Mestrado) Arquitetura e Urbanismo, Universidade de São Paulo (FAU), São Paulo, SP, Brasil.

Sá, M. B. de. (2000). A paisagem recriada: um olhar sobre a cidade de Campina Grande. In: E. de Q. Gurjão. Imagens multifacetadas da história de Campina Grande (pp. 179-189). Campina Grande: PMCG.

Silva, J. G. de A. e. (2000). Raízes históricas de Campina Grande. In: E. de Q. Gurjão. Imagens multifacetadas da história de Campina Grande (pp.13-28). Campina Grande: PMCG.

SUDENE. (2017). Institucional. Recuperado de: <http://www.sudene.gov.br/institucional> .

TICCIH. (2003, julho). The International Committee for the Conservation of the Industrial Heritage. Carta de Nizhny Tagil sobre o Patrimônio Industrial. 